\title{
The Antioxidant Effects of Flavonoids and non Flavonoid Part Extracted from Ginger ( Zingiber Officinale) Roots.
}

\author{
Sameira M. Al- Katib \\ Elham M. Al- Khashab \\ Man S. Kalo \\ Ameira A. Hamdoon \\ Department of Physiology \\ College of Veterinary Medicine \\ Mosul University
}

(Received 22 / 10 / 2008 ; Accepted 15 / 6 / 2009)

\begin{abstract}
The extraction of Flavonoids from dried ginger ( Zingiber officinale Ros.) roots in addition of non-flavonoids parts (oils and defatted) were studied against $\mathrm{H}_{2} \mathrm{O}_{2}$ induced oxidative stress in the serum of male rats for 15 day.

Fifty male rats with age of 3-4 months and weight of 225-300 g were divided into 5 groups : group (1): control group received drinking tab water and ideal diet, group (2): received $0.5 \% \mathrm{H}_{2} \mathrm{O}_{2}$ in drinking tab water, group (3): received $0.5 \% \mathrm{H}_{2} \mathrm{O}_{2}$ and oral dose of $15 \mathrm{mg} / \mathrm{kg}$ of BW. flavonoids once daily, group (4): received $0.5 \% \mathrm{H}_{2} \mathrm{O}_{2}$ and oral dose of $30 \mathrm{mg} / \mathrm{kg}$ BW flavonoids once daily. Group (5): received $0.5 \% \mathrm{H}_{2} \mathrm{O}_{2}$ and the experimental $\operatorname{diet}(50 \mathrm{~g}$ non- flavonoids part $/ \mathrm{kg}$ diet).

$\mathrm{H}_{2} \mathrm{O}_{2}$ treated group showed elevation in serum cholesterol, malondialdehyde (MDA), peroxynitrite radical levels and reduction in glutathione (GSH), vit $\mathrm{C}$, albumin, calcium, and phosphorus levels compared with the control group $(\mathrm{p} \leq 0.05)$. Treatment with ginger extracts counteracted the oxidative stress induced by $\mathrm{H}_{2} \mathrm{O}_{2}$ by reducing the levels of cholesterol, MDA and peroxynitrite and enhancing the levels of GSH, vit C, albumin and calcium compared with the $\mathrm{H}_{2} \mathrm{O}_{2}$ treated group $(\mathrm{p} \leq 0.05)$. Treatment with non flavonoids part, by means of experimental diet, showed decreasing in the MDA, peroxynitrite, phosphate levels and increasing in vit $\mathrm{C}$ level compared with the $\mathrm{H}_{2} \mathrm{O}_{2}$ treated group $(\mathrm{p} \leq$ 0.05 ). The results of the present study provided the protective effects of the ginger extract by increasing antioxidant defense and suppression free radicals production in the serum.
\end{abstract}

Keywords: ginger, flavonoids, oxidative stress, antioxidants. 


\section{التأثيرات المضادة للألسة الفلافونوبدك والجزء غير الفلافونوبي الهستخلصة من جنور الزنجبل فئل}

\section{ll}

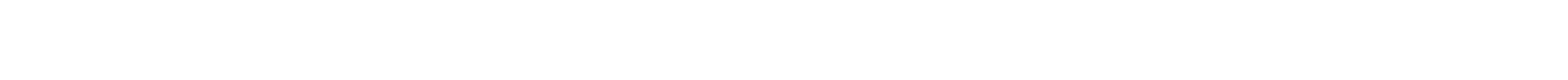

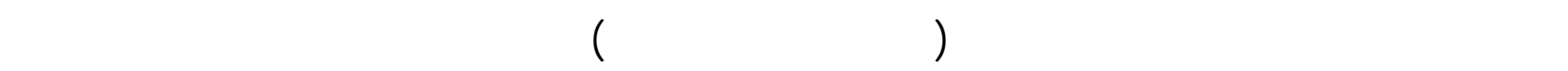
بيروكسيد الهيدروجين في مصل نكور الجرذان البالغة لمدة 15 يوما.

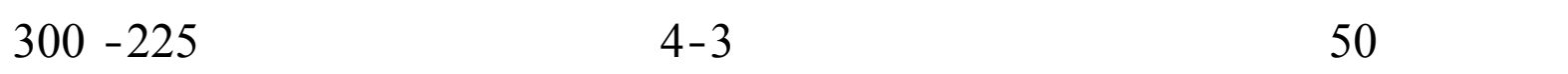
غم. قسمت عثروائيا إلى 5 مجلمبع متساوية: (1) مجموعةسيطرة لستهلكت ماء للثرب الاعتيادي والغ ـذاء القيلسي، (2) مجموعة عوملت ببيروكسيد الهيدروجين (H2

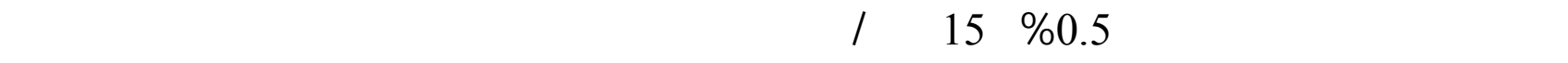

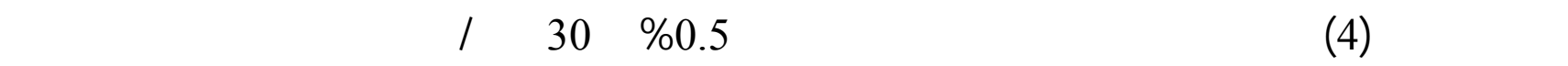
يومية عنطريق الفم، (5) مجموعة عوملت ببيروكسيد الهيدروجن 0.5\% والغذاء المضف إليه \% \% مـ ن الجزء غير الفلافونويدي من النبلت. لظهرت المجموعة المعلملة بـ - $\mathrm{H}_{2} \mathrm{O}_{2} \mathrm{O}_{2}$

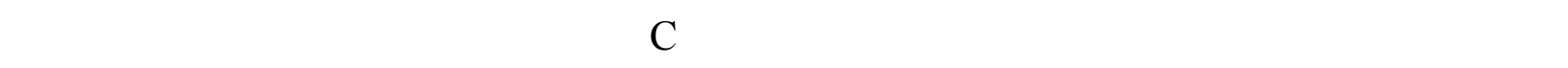

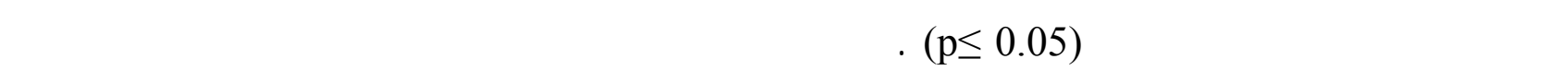

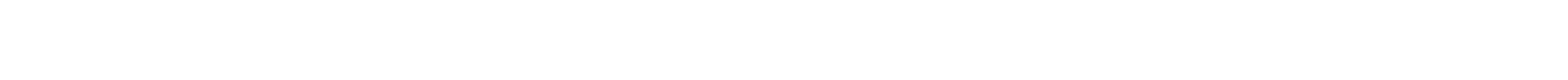

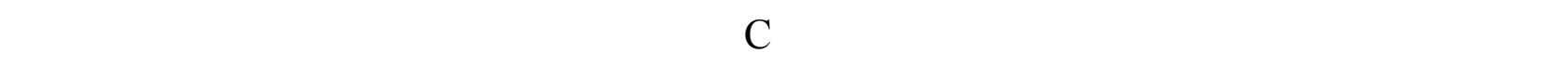

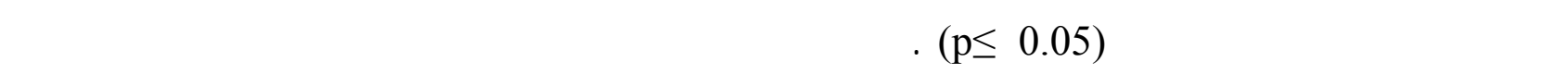

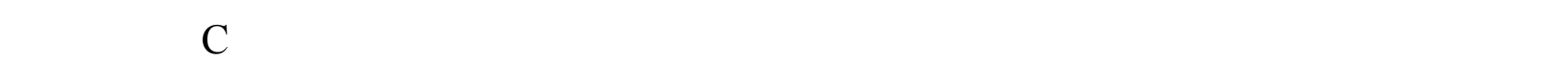

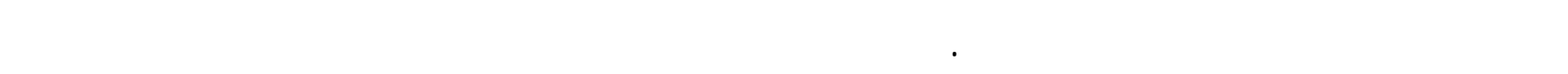
الأوكسجن الفعالة عنطريق زيادة إنتاج مضادات الأمسدة وكنح الجذور الحرة في الدم.

\section{INTRODUCTION}

The ginger ( Zingiber officinale Rosce, Zingiberaceae) approximately $2-3 \mathrm{~cm}$. in length, is one of the more commonly used herbal supplements (Langer et al., 1998) it is taken by many patients to treat a variety of conditions (Ghayur et al., 2005) its root has been used for perhaps thousands of years in the Far East to treat inflammatory diseases (Shen et al., 2003) and also shown to be effective for pregnancy- induced and postoperative nausea and vomiting (White, 2007). Ginger is rich in volatile oils including zingiberene, zingiberole, gingerol, shogoal, phellandrene, Borneol, Cineole, as well as citral, starch, 
mucilage and resin. Different varieties of ginger contain different essential oils (Langner et al., 1998).

Ginger showed an antioxidant activity (Cao et al., 1993). 6- Gingerol is one of the major antioxidant of fresh ginger and has antioxidant, antiapoptitic, anti- inflammatory and pharmacologic activities in vitro and in vivo (Kim et al. , 2007). The structure of more than 50 antioxidants isolated from the rhizomes of ginger were determined. The isolated antioxidants divided into two groups: gingerol related compounds with an alkyl group bearing 10- 14 carbon chain length, and diaryl heptanoids ( Masuda et al., 2004). The antioxidant activities of these compounds were evaluated by their free radical scavenging and inhibitory of autooxidation of lipids (Ahmed et al., 2000 a).

Ginger extract tested positive for saponins, flavonoids, amines, alkaloids and terpenoids. The hypotensive, vasodilation and cardiosuppressant effects of its aqueous extract has been reported Stimulation of muscarinic receptors and blockade of $\mathrm{Ca}^{+2}$ channels were also been reported (Ghayur et al., 2005).

Few studies have demonstrated the flavonoids activities of ginger. The present study was designed to evaluate the effect of alcohol extracted flavonoids administrated orally on the oxidative stress in $\mathrm{H}_{2} \mathrm{O}_{2}$ - induced rats. The effect of nonflavons part in the diet supplement was also investigated.

\section{MATERIAL AND METHODS}

Flavonoids extraction: The dried powdered roots of the ginger was obtained from local markets. Sixty grams were extracted with diethyl ether using soxhlet apparatus for 3 hours to remove fatty contents (Tyler, 1993). The defatted plant material was dried at $35 \mathrm{C}^{\circ}$ in an air oven, and then extracted at room temperature with two aliquots of $500 \mathrm{ml}$ of methanol. The extract containing the flavonoids was concentrated to a final volume of approximately $50 \mathrm{ml}$ using rotary evaporator. This extract (Flavonoids part) was dried completely in an air oven at a temperature of $35 \mathrm{C}^{\circ}$ (Wagner, 1986).

Experimental diet: The nonflavons plant materials (oil and defatted plant material) were mixed with the standard animal diet in concentration of $5 \% \mathrm{w} / \mathrm{w}$.

Animals: Fifty albino male rats (weight of 225- 300 g, age of 3-4 months) were divided randomly into five groups, each group was housed in communal cage, water in polyethylene bottles was available as drinking water, room temperature was maintained between 22-25 $\mathrm{C}^{\circ}$. Animals in each group received once daily for 15 day (experimental period ) the following :-

Group (1): drinking water and standard diet (control ).

Group (2): $0.5 \% \mathrm{H}_{2} \mathrm{O}_{2}$ in drinking water.

Group (3): $0.5 \% \mathrm{H}_{2} \mathrm{O}_{2}$ and $15 \mathrm{mg} / \mathrm{kg} \mathrm{BW}$. oral dose of flavonoids.

Group (4): $0.5 \% \mathrm{H}_{2} \mathrm{O}_{2}$ and $30 \mathrm{mg} / \mathrm{kg} \mathrm{BW}$. oral dose of flavonoids.

Group (5): $0.5 \% \mathrm{H}_{2} \mathrm{O}_{2}$ and the experimental diets contain $5 \%$ non flavonoid part.

At the end of the experimental period, animals were sacrified, $(5 \mathrm{ml})$ of blood were collected from each animal and the serum was separated.

Chemical tests: Serum cholesterol was estimated enzymatically using Kit manufactured by Syrbio company, the quinineimine complex formed was measured at $500 \mathrm{~nm}$.

Malodialdehyde (MDA) was determined in the serum by the method of (Beuge and Aust, 1978) using Thiobarbituric acid (TBA), the color formed was read at $532 \mathrm{~nm}$. 
The glutathione content (GSH) was measured in serum by the reaction with [5,5- dithiobis (2- Nitrobenzoic acid)] (DTNB) using the method of (Burtis and Ashwood, 1999). The reduction reaction was read at $412 \mathrm{~nm}$.

Peroxynitrite radical was assayed in serum by the nitration of phenol using the method of (Vanuffelen et al., 1998). the nitrophenol content formed was read at $412 \mathrm{~nm}$.

Albumin concentration was determined in serum by the Bromocresol green method (Kit manufactured by Syrbio Company).

The concentration of ascorbic acid (vit C) was determined in serum by the method of (Colowick- Kaplan, 1979) using hydrazine, thiourea, copper reagent. The Bis- 2,4dinitrophenyl hydrazone complex was read at $520 \mathrm{~nm}$.

Serum uric acid was enzymatically assayed (Kit manufactured by Biolabo SA). The red quinoneimine complex formed by uricase was measured at $520 \mathrm{~nm}$.

Serum total calcium was determined using commercial Kit (manufactured by BioMerieux company). Calcium in the sample reacts with O- cresolphthalin complexone (CPC) at alkaline $\mathrm{pH}$, the colored complex formed was measured at $570 \mathrm{~nm}$.

Serum inorganic phosphorus was determined using commercial Kit (manufactured by BioMerieux company) The phosphomolybdate complex formed in the presence of a reducing agent (ferrous sulfate) was measured at $690 \mathrm{~nm}$.

Statistical analysis: standard statistical methods were used to determine the mean and standard deviation (S.D). Unpaired t- test was used to compare the means of flavonoidtreated groups with control on one aspect and with $\mathrm{H} 2 \mathrm{O} 2$ - treated group on the other aspect for various parameters (S.

\section{RESULTS AND DISCUSSION}

Cholesterol concentration: The results in figure (1) showed a significant reduction in cholesterol level in groups treated with 15 and $30 \mathrm{mg} / \mathrm{kg}$ of flavonoids compared with the $\mathrm{H}_{2} \mathrm{O}_{2}$ treatment group ( $\mathrm{p} \leq 0.05$ ) Fig (1). This result was similar to that obtained by (Masuda et al., 2004) who mentioned that the gingerol related compounds substituted with alkyl group, might contribute to both radical scavenging effect and inhibitory effect of lipid autooxidation. (Fuhrman et al., 2000) explained the role of ginger extract in reducing the development of aortic atherosclerotic lesions, along with an impressive reduction in the levels of plasma LDL- cholesterol in atherosclerotic mice. Hypolipidemic and antiatherosclerotic effects of ginger extract were also demonstrated in cholesterol- fed rabbits (Bhandari et al., 1998, Sharma et al., 1996). 


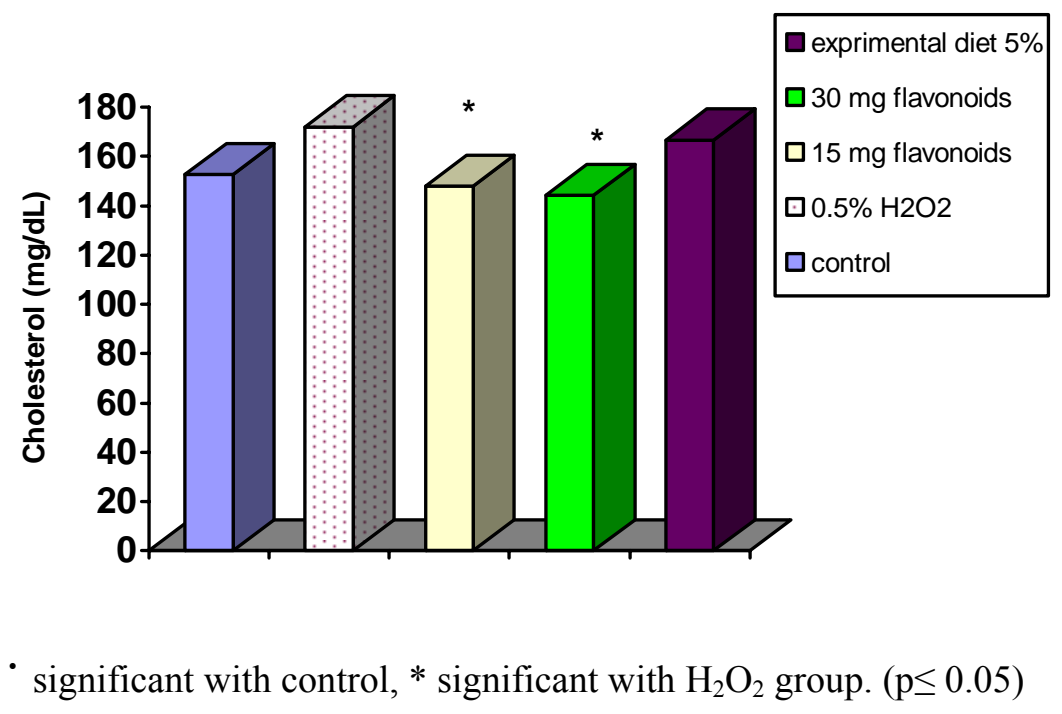

Fig.1: Effect of ginger extracts on cholesterol level.

The hypocholesterolemic effect of ginger could have possibly resulted, at least in part, from the inhibition of cellular cholesterol biosynthesis. Reduced cellular cholesterol biosynthesis is associated with increased activity of the LDL- receptors which in turn leads to enhanced removal of LDL from plasma, resulting in reduced plasma cholesterol concentration (Ness et al., 1996). These results are in agreement with data showing that plant foods possess cholesterol- suppressive capacity (O'Brien and Reiser, 1979), also act as hypocholesterolemic agent due to their inhibitory effect of cellular cholesterol biosynthesis (Fuhrman et al., 1997b). Reduction of atherosclerotic lesion development along with reduced LDL oxidation was demonstrated in apolipoprotein E- deficient mice supplemented with the two red wine flavonoids, catechin and quercetin (Hayek et al., 1997) suggested that LDL oxidation can lead to modification of lipoproteins and LDL aggregation, aggregated LDL are taken up by macrophages at enhanced rate, leading to cellular cholesterol accumulation and foam cell formation (Aviram 1993b, Heinecke et al., 1991, Suits et al., 1989).

MDA concentration: The MDA level increased significantly following $\mathrm{H}_{2} \mathrm{O}_{2}$ treatment $(\mathrm{p} \leq$ 0.05 ) compared with the control group (Fig 2). This result was explaine the important role of $\mathrm{H}_{2} \mathrm{O}_{2}$ as a potent oxidizing agent which cause the oxidative stress by increasing the reactive oxygen species (ROS) or decreasing the antioxidant defense systems. Halliwell explained the oxidative stress statement and the role of free radical in the participitation of many diseases (Halliwell, 1993). $\mathrm{H}_{2} \mathrm{O}_{2}$ was used to induce many diseases including oxidative stress, such as atherosclerosis and diabetes melutus (Aziz, 2001, Wohaieb et al., 1994). 


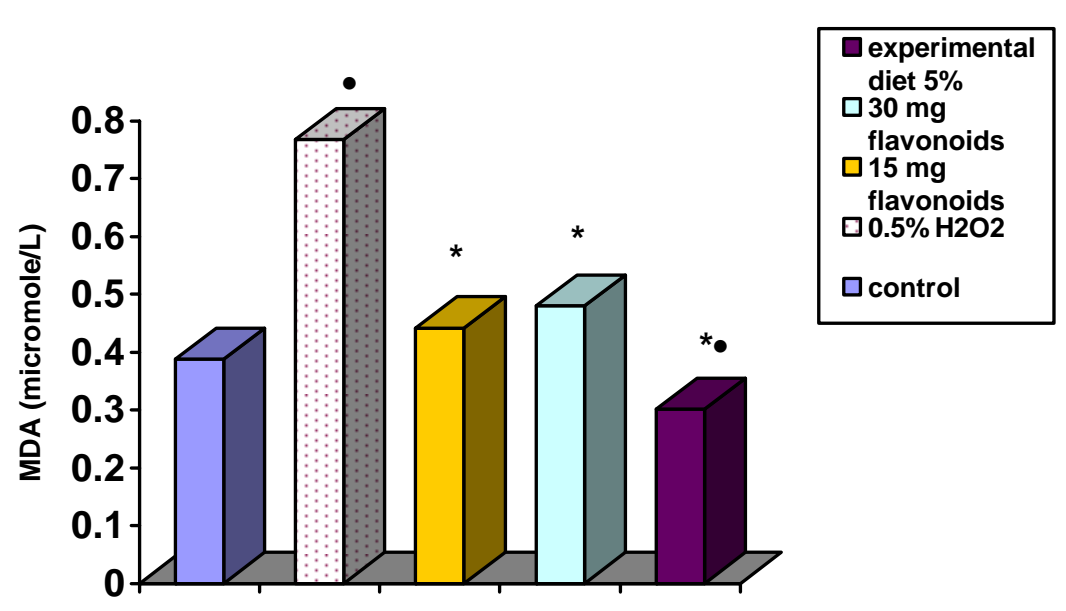

- significant with control, * significant with $\mathrm{H}_{2} \mathrm{O}_{2}$ group. $(\mathrm{p} \leq 0.05)$

Fig. 2: Effect of ginger extract on MDA level.

Flavonoids- treated groups reversed the increase of MDA level to a considerable extent, (fig 2). It is now well established that Zingiber officineles rose significantly attenuated lipid peroxidation (Ahmed et al., 2000b)and has antioxidant properties by maintaining the activities of Superoxide dismutase (SOD), Catalase and glutathione Peroxidase (Ahmed et al., 2000a). Also, $200 \mathrm{mg} / \mathrm{kg}$ of ethanolic Zingiber officinale extract administered for 20 day, showed to enhance the antioxidant defense SOD, catalase and tissue glutathione against isoproternol- induced oxidative myocardial necrosis in rats (Ansari et al., 2006).

(Shanmuga- sundaram et al., 1994) explained the effect of Amrita Bindu, the ginger naturally occurring salt, in the protection against free radical and ROS induced tissue lipid peroxidation in blood and liver when exposed to a carcinogenic nitrosamine and N- methyl$\mathrm{N}$ - nitro- N- nitrosoguanidine.

GSH concentration: Fig (3) showed a significant decrease in GSH level in $\mathrm{H}_{2} \mathrm{O}_{2}$ - treated group ( $\mathrm{p} \leq 0.05$ ) compared with the control group.. This result is in agreement with that obtained by (Ahmed et al., 2000b) who explained that dietary feeding of ginger $(1 \% \mathrm{w} / \mathrm{w})$ increased GSH level in whole blood of rats treated with $20 \mathrm{ppm}$ of malathion, a chemical pesticide, for 4 weeks. Also, (Ahmed et al., 2000a) mentioned that dietary ginger $(1 \% \mathrm{w} / \mathrm{w})$ is comparatively as effective as ascorbic acid in increasing blood GSH in rats. The results is also in agreement with previous study showing that the pretreatment of ethanolic zingiber extract $(200 \mathrm{mg} / \mathrm{kg})$ for 20 day, enhance endogenous myocardial antioxidants, GSH, Catalase and Superoxide dismutase against isopropanol- treated rats (Ansari et al., 2006). 


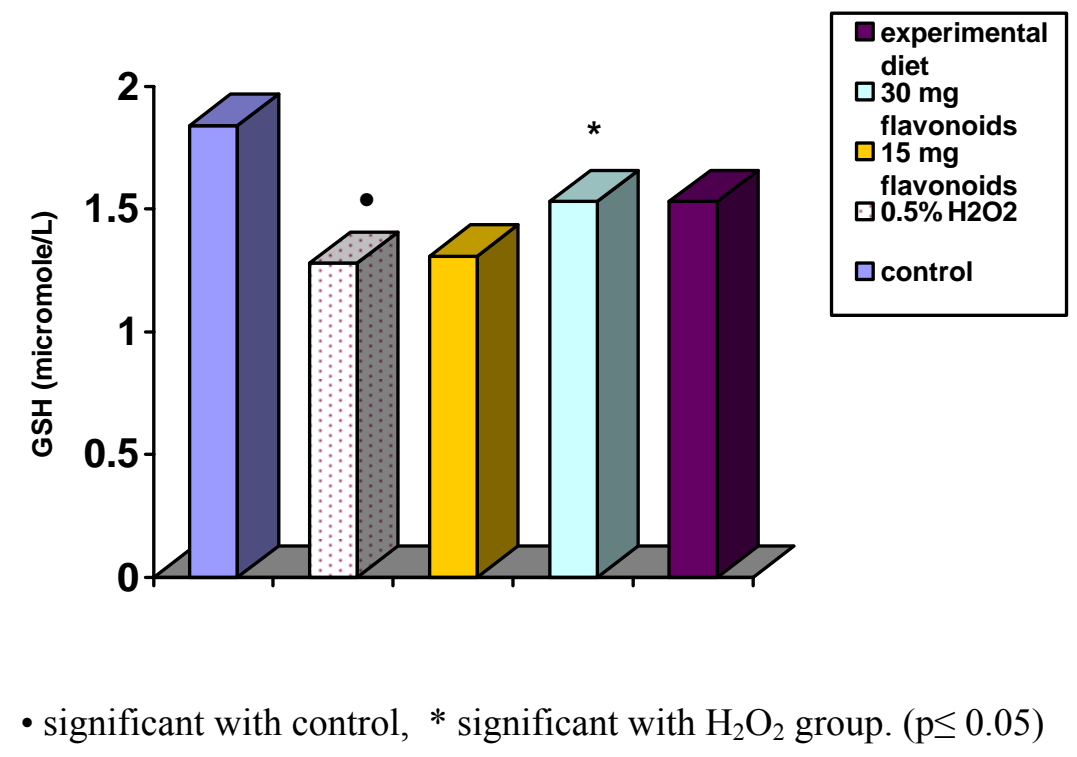

Fig. 3: Effect of ginger extract on GSH level.

A study of (Shanmugasundaram et al., 1994) showed that Amrita- Bindu, increased blood and liver GSH and provide protection against free radical and ROS induced by nitrosamine.

ONOO $^{-}$concentration: The results of Peroxynitrite concentration showed a significant decrease in all Ginger- treated groups compared with the control and $\mathrm{H}_{2} \mathrm{O}_{2}$ - treated groups $(\mathrm{p} \leq 0.05)$. This result was similar to that obtained by (Lippoushi et al., 2003) who explained that the 6- gingerol, a flavonoid present in ginger, is a potent inhibitor of nitric oxide synthesis and an effective protector against peroxinitrite- mediated oxidation and nitration reaction, in activated mouse macrophages ( Lishen et al., 2005) explained the inhibitory effects of ginger root extract on the production of inflammatory mediators including nitric oxide (NO) and prostaglandin E2 (PGE2) in chondrocytes isolated from sow cartilage explants.

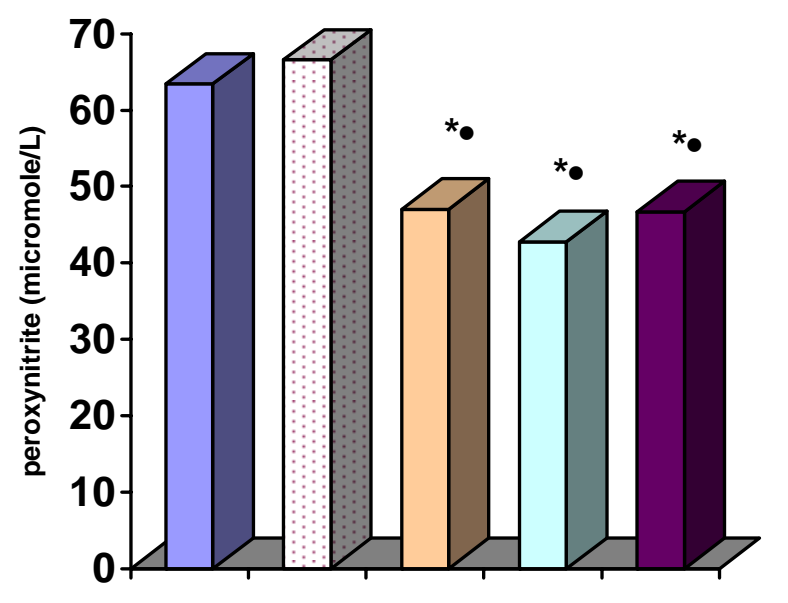

$\square$ experimental diet $5 \%$
$\square 30 \mathrm{mg}$ flavonoids
$\square 15 \mathrm{mg}$ flavonoids
$\square 0.5 \% \mathrm{H} 2 \mathrm{O} 2$
$\square$ control

- significant with control, * significant with $\mathrm{H}_{2} \mathrm{O}_{2}$ group. $(\mathrm{p} \leq 0.05)$

Fig. 4: Effect of ginger extracts on Peroxynitrite level. 
Albumin concentration: Group treated with $15 \mathrm{mg} / \mathrm{kg}$ flavonoid showed a significant increase in serum albumin, Fig (5) compared to the control and $\mathrm{H}_{2} \mathrm{O}_{2}$ treated groups $(\mathrm{p} \leq$ 0.05) (Patterson et al., 2007) explained the interaction between the albumin and flavonoids. The quercetin which is a major flavonoid found in most natural food, is bound to human serum albumin at physiologically correlated concentration.

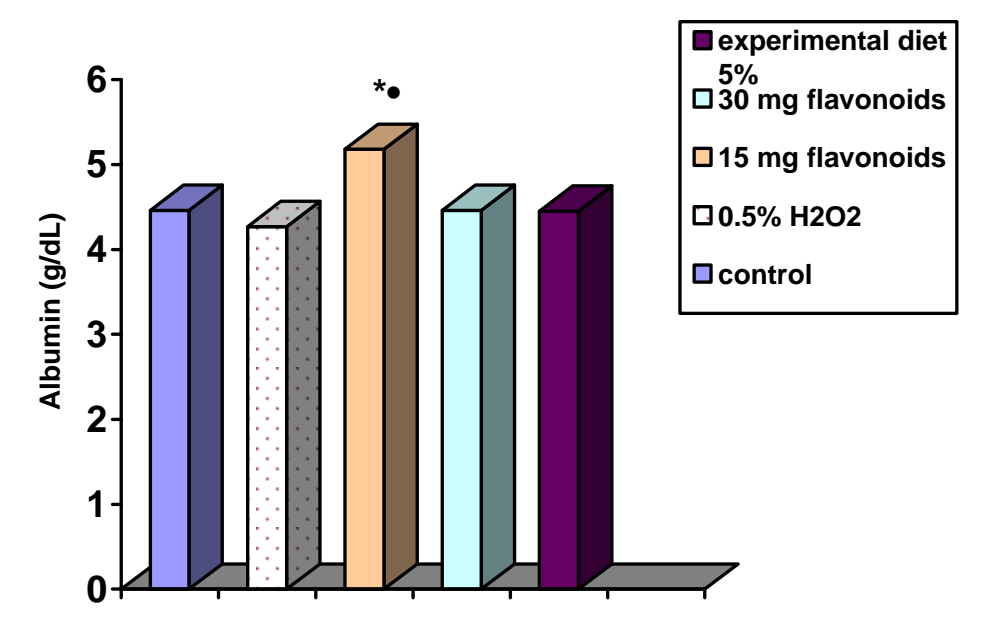

- significant with control, * significant with $\mathrm{H}_{2} \mathrm{O}_{2}$ group. $(\mathrm{p} \leq 0.05)$

Fig. 5: Effect of ginger extract on albumin level.

Spectroscopic studies show that $80 \%$ of alpha tocopherol radical $(\alpha-$ Toc $o$ ) are repaired over several seconds by quercetin bound to human serum albumin. $\alpha$ TOC O generated by the oxidation of Tryptophan and Tyrosine residues of apolipoproteins AI and AII, in HDL and apolipoprotein E in LDL produces the corresponding species Tyro and Try, This species are repair by endogenous alpha Toc-OH (Patterson et al., 2007) . In addition, (Banerjee et al., 2008) in recent investigations report a study on the interactions of the flavone, 7- hydroxyflavone (7HF) with the plasma human albumin and acting against the tryptophan oxidation. On the other hand, (Murota et al., 2007) showed that the quercetin is metabolized in the intestinal mucosa and liver, and is present as glucuronide sulfate conjugates. This quercetin is known to possess strong antioxidant activity when its metabolized, more than $80 \%$ of quercetin metabolites were localized in the human plasma albumin and lipoprotein generated antioxidant activity against LDL oxidation.

Vit $C$ concentration: $\mathrm{H}_{2} \mathrm{O}_{2}$ treated group showed a significant reduction in vit $\mathrm{C}$ level compared with the control group $(\mathrm{p} \leq 0.05)$. The ginger extracts counteracted the $\mathrm{H}_{2} \mathrm{O}_{2}$ induced oxidative stress, Fig (6), $30 \mathrm{mg} / \mathrm{kg}$ of flavonoid treated group showed a significant increase in vit $C$ level $(p \leq 0.05)$ this is the same result with that obtained by (Shanmuga sundaram, 1994) who explained that ginger supplementation prevented depletion of the antioxidant enzymes and vitamins A,C and E.

The non flavonoids part of the ginger roots showed a significant decrease in MDA and peroxynitrite level, and a significant increase in vit $\mathrm{C}$ level compared with the $\mathrm{H}_{2} \mathrm{O}_{2}$ - treated group $(p \leq 0.05)$. Many studies showed the bioactivity of ginger consitituents and is commonly useful for treating an upset stomach, preventing symptoms of nausea and motion sickness (Chrubasik et al., 2005). It's activity to reduce the risk of blood clott formation 
makes it a useful herb for lowering the risk of cardiovascular diseases (Guh et al., 1995). (Ghayur et al., 2005) showed that ginger is rich in essential fatty acids which can react with the toxins stored in the body From chemicals found in food. In addition, (Ghayur and Gllani, 2006) showed that is probably to use the whole herb rather than other fractional supplements since there may be other compounds found in the whole herb such as terpenoids, alkaloids, gingerols and diarylheptanoids that possess anti- mutagenic, antiinflammatoryactivity and exhibit a strong antioxidant activity similar to that of vit $\mathrm{E}$.

Ginger also inhibit various cancers due to the presence of antioxidant curcumin, a substance that reported to stimulate the activity of glutathione-s- transferase, an enzyme which assists in the elimination of cancer- causing substances from the body (Hertog et al., 1995).

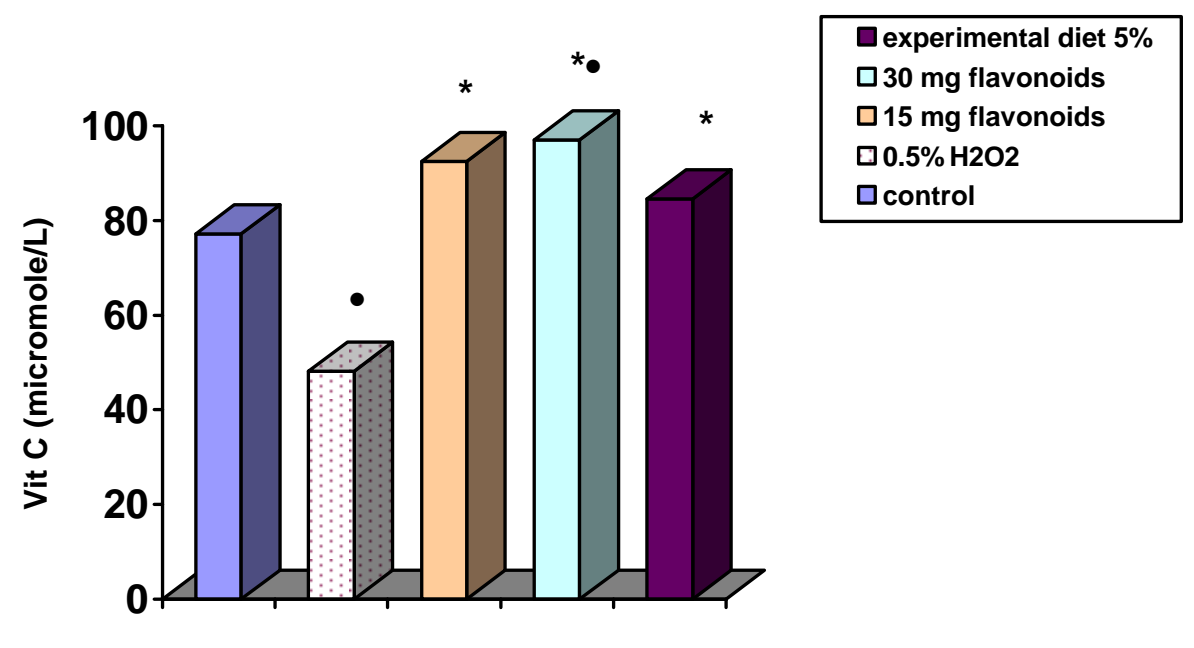

- significant with control, * significant with $\mathrm{H}_{2} \mathrm{O}_{2}$ group. $(\mathrm{p} \leq 0.05)$

Fig. 6: Effect of ginger extract on vitamin $\mathrm{C}$ level.

Uric acid concentration: $\mathrm{H}_{2} \mathrm{O}_{2}$ - treated group showed a significant increase in uric acid (Fig 7) compared with the control group $(\mathrm{p} \leq 0.050 .30 \mathrm{mg} / \mathrm{kg}$ ginger flavonoids reduced the level of uric acid compared with $\mathrm{H}_{2} \mathrm{O}_{2}$ - treatment group $(\mathrm{p} \leq 0.05)$, this result is in agreement with the result obtained by (Bliddal et al., 2000) showing that the ginger helps the body to get ride of the excess uric acid and prevents gout attacks. (Chrubasik et al., 2005) mentioned that alcohol inhibits kidney function which results in more uric acid in blood, and quercetin, the major flavonoid in many plants, inhibits uric acid production in a similar fashion to commonly drugs for gout. 


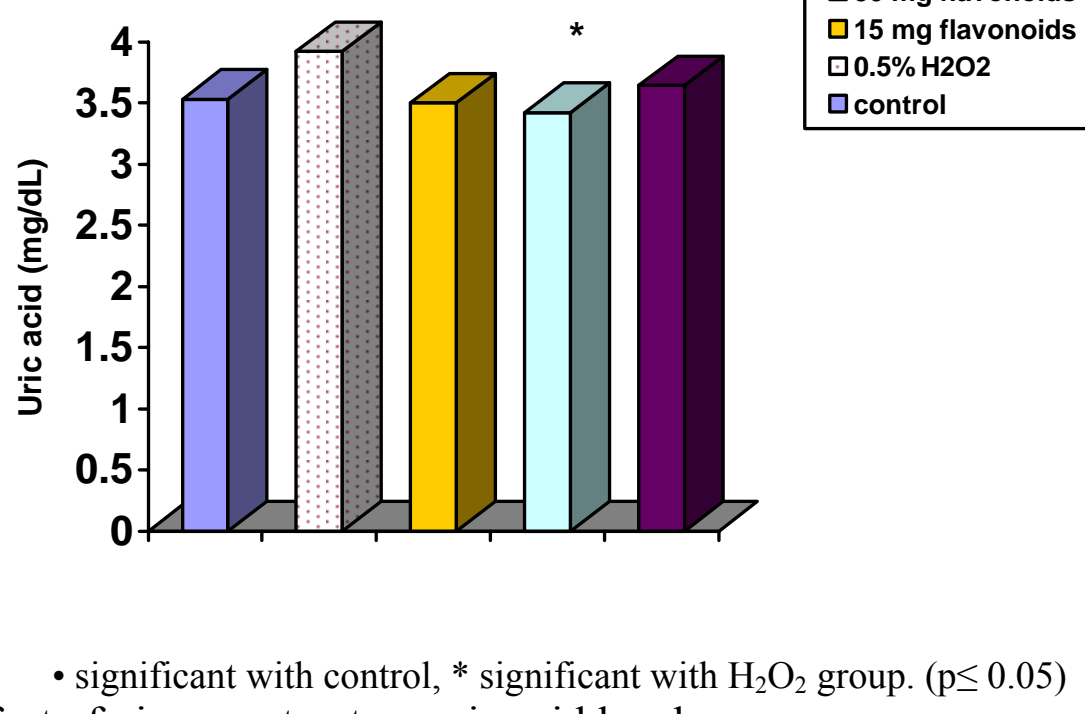

Fig. 7: Effect of ginger extract on uric acid level.

The eleimination of uric acid from the tissues by ginger was demonstrated by (Ozaki et al., 1991) showing that ginger is high in flavonoids which helpful in overcoming uric acid.

$\mathrm{Ca}$ and $\mathbf{P}$ concentration: The result in Fig ( 8 and 9 ) showed a significant reduction in $\mathrm{Ca}$ and $\mathrm{P}$ levels in $\mathrm{H}_{2} \mathrm{O}_{2}$ - treated group compared with the control group $(\mathrm{p} \leq 0.05)$ Treatment with flavonoids $\left(30 \mathrm{mg} / \mathrm{kg}\right.$ ) counteracted the effect of $\mathrm{H}_{2} \mathrm{O}_{2}$ on the Ca concentration ( $\mathrm{p} \leq$ 0.05) Although ginger root has been used for perhaps thousands of years to treat inflammatory diseases including osteoarthritis, however, the effect of ginger root has never been evaluated on the $\mathrm{Ca}$ and $\mathrm{P}$ levels.

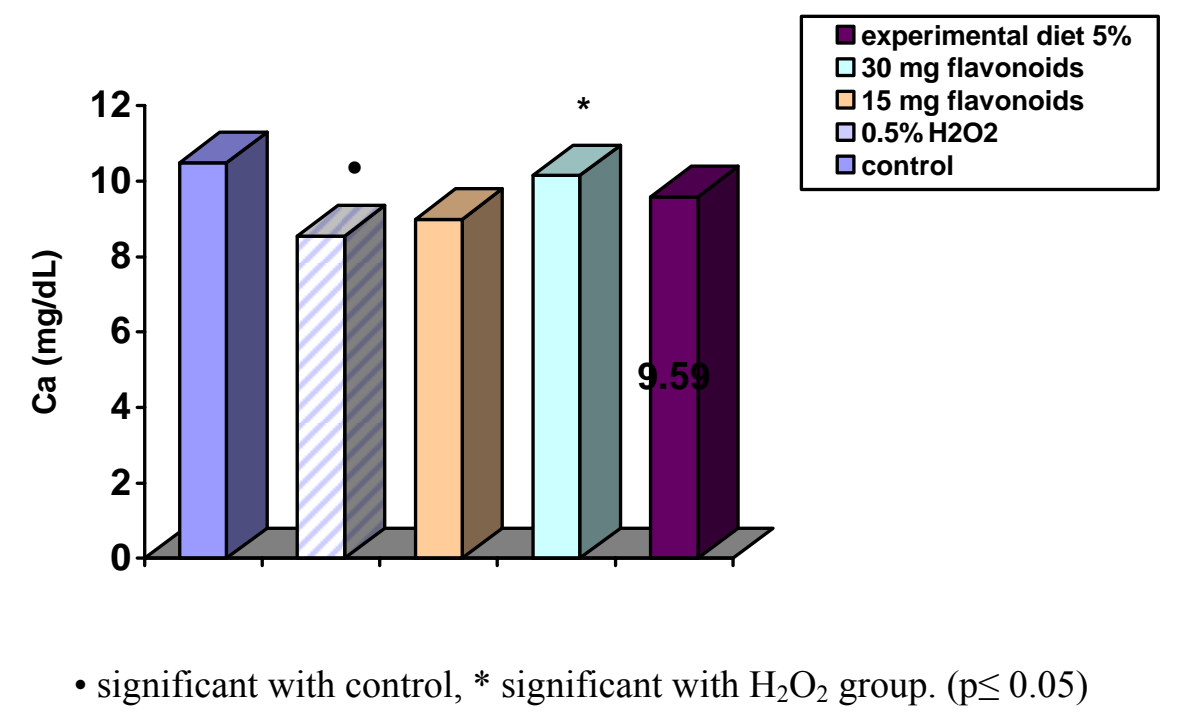

Fig. 8: Effect of ginger extract on calcium level.

Many previous study demonstrated the anti- arthritic effect of ginger root. (Chen et al.,2003) explained its anti- arthritic effect in sow cartilage explants. (Lishen et al., 2005) explained the important role of ginger root extract as an anti- arthritic agent by reducing the 
production of inflammatory mediators including nitric oxide (NO) and prostaglandin E2 (PGE2) in normal chondrocytes and osteoarthrotic chondrocytes. (Altman and Marcussen 2001) studied its effect in 261 people with osteoarthritis knee pain and suggested that ginger root extract may be considered as a potentially useful in combination with ibuprofen, a medication frequently used in reducing symptoms of osteoarthritis. However, our study is in agreement with (Yamaguchi et al., 2007) who explained the action of various flavonoids (quercetin, myricetin, kaempferol, isorhamnetin and curcumin ) on bone calcium content and osteoclastogenesis in rats. This study demonstrated that various flavonoids have a potent inhibitory effect on osteoclastogenesis and bone resorption, and had a stimulatory effect on bone formation when cortical bone and trabecular bone tissues were cultured for 7 days in the presence of parathyroid hormone PTH, a bone- resorbing factor. The decreasing in phosphate level after flavonoids treatment may be explained as a result of parathyroid hormone (PTH) secretion that influence the both calcium and phosphate homeostasis in tissues and extracelular fluids (Bringhurst, 1995). PTH in serum, increase total and free $\mathrm{Ca}$ and reduce the concentration of phosphate (Potts et al., 1995).

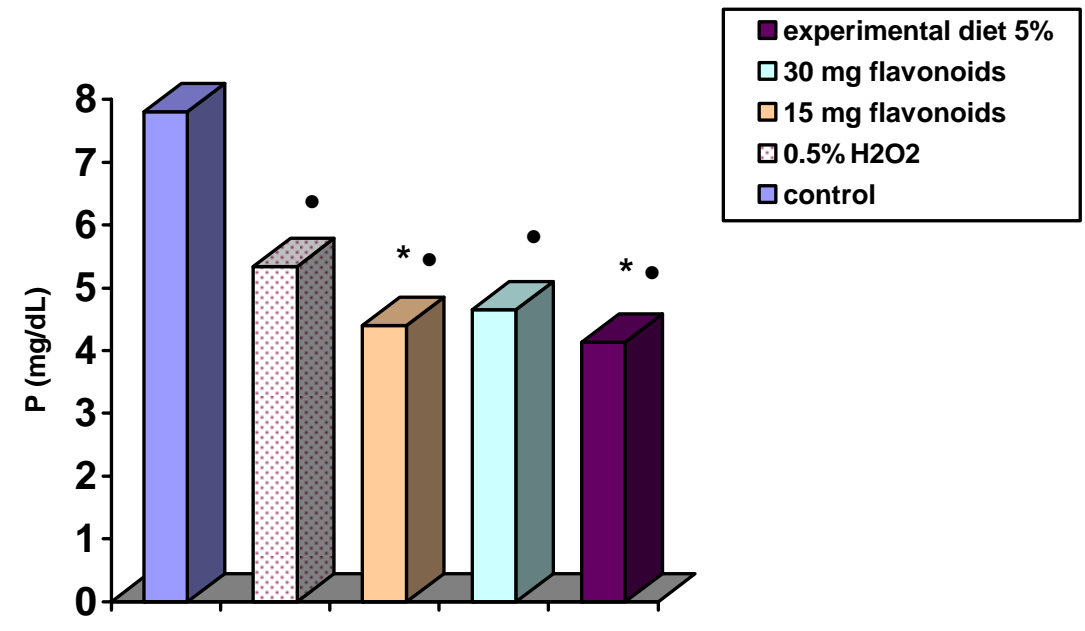

- significant with control, * significant with $\mathrm{H}_{2} \mathrm{O}_{2}$ group. $(\mathrm{p} \leq 0.05)$

Fig. 9: Effect of ginger extract on phosphorus level.

Recently the antioxidant properties of natural flavonoids and related phenolic compounds extracted from dietary or herb plants have aroused much attention due to its structure that included aromatic rings and electrons transport. Plants rich in these compounds are ideal sources of natural antioxidants (Van Acker et al., 1996). it has been shown in this study that flavonoid components isolated from the root extract of ginger have the free radical scavengering and protective effects on oxidative responses, recent reports have implied that oxygen free radical is important mediator of tissue injuries and lipid peroxidation reaction. Lam et al., 2007) We suggest that the protective effect of the alcoholic extract of Zingiber officinalis may be due to increasing antioxidant defense and suppression of free radical production in the blood. 


\section{REFERENCES}

Ahmed, R. S.; Seth, V.; Baneriee, B.D. (2000 a). Influence of dietary ginger (Zingiber officinale Rosc.) on antioxidant defense system in rat: Comparison with ascorbic acid. Indian J. Exp. 38(6), 604- 606.

Ahmed, R. S.; Seth, V.; Pasha, S.T.; Baneriee, B.D. (2000 b). Influence of dietary ginger (Zingiber officinale Rosc) in oxidative stress induced by malathion in rats. Food Chem. Toxicol., 38(5), 443- 450.

Ansari, M. N.; Bhandari, U.; Pillai, K.K. (2006). Ethanolic Zingiber officinale R. extract pretreatment alleviates isoproterenol- induced oxidative myocardial necrosis in rats. Indian J. Exp. Biol., 44(11), 892- 897.

Aviram, M. (1993). Modified forms of low density lipoprotein and atherosclerosis. Atherosclerosis, 98, 1-9.

Aziz, B. N. (2000). Effect of hydrogen peroxide induced oxidative stress on epiclidymal sperm of mice. Iraqi J. Vet. Sci., 13(1), 61- 65.

Banerjee, A.; Basu, K.; Sengupta, P.K. (2008). Interaction of 7- hydroxyflavone with human serum albumin: spectroscopic study. J. Photochem. Photobiol. B., 90(1), 33- 40.

Beuge, J. A.; Aust, S.D. (1978). "Estimation of Serum Malondialdehyde Level". Methods in Enzymology. Academic Press. London, 51: 302p.

Bhandari, U.; Sharma, J. N.; Zafar, R. (1998). The protective action of ethanolic ginger (Zingiber officinales) extract in cholesterol fed rabbits. J. Ethnopham., 61(2), 167- 171.

Bliddal, H.; Rosetzsky, A.; Schlichting, P. (2000). A randomized placebo- controlled, crossover- study of ginger extracts and ibuprofen in osteoarthritis. Osteoarthritis cartilage, 8(1), 9-12.

Bringhurst, F.R. (1995). "Calcium and Phosphate Distribution. Turnover, and Metabolic Actions" In: Endocronology, 3rd edn. Vol. 2 . L. J. DeGroot. Ed. Philadelphia, W.B. Saunders. pp. 1015-1043.

Burtis, C. A. ; Ashwood, E. R. (1999). "Tietz Textbook of Clinical Chemistry". 3rd edn. W.B. Saunders Co., USA.

Cao, Z. F.; Chen, Z. G.; Guo, P.; Zhang, S.M.; Lian, L.X.; Luo, L.; Hu, W.M. (1993). Scavengingeffects of a ginger on superoxide anionand hydroxyl radical. ChungKuo Chung YaoTsa Chih; 18, 750-764.

Chrubasik, S.; Pittler, M.H.; Roufogalis, B. D. (2005). Zingeberis rhizome: a comprehensive review on the ginger effect and efficacy profiles. Phytomedicine, 12(9), 684- 701.

Colowick, S.P. ; Kaplan, N.O. (1979). "Methods in Enzymology". Vol. 62, part D, Academic Press Inc., USA, 7p.

Fuhrman, B.; Elis, A.; Aviram, M. (1997). Hypocholesterolemic effect of lycopene and $\beta$ carotene is related to suppression cholesterol synthesis and augmentation of LDL receptor activity in macrophages. Boichem. Biophys. Res. Commun. 233, 658622.

Fuhrman, B.; Rosenblat, M.; Hayek, T.; Coleman, R.; Aviram, M. (2000). Ginger extract reduces plasma cholesterol, inhibits LDL oxidation, and attenuates development atherosclerosis in atherosclerotic, apolipoprotein E- deficient mice. J. Nutr., 5, 1124-1131. 
Ghayur, N. N.; Gilani, A.H.; Afridi, M.B.; Houghton, P. I. (2005). Cardiovascular effects of ginger aqueous extract and its phenolic constituents are mediated through multiple pathways. Vascul Pharmacol., 43(4), 234- 241.

Guh, J.H.; Ko, F. N.; Jong, T.T.; Teng, C.M. (1995). Antiplatelet effects of gingerol isolated from Zingiber officinale. J. Pharm. Pharmacol. 47, 329-332.

Halliwell, B. (1994). Free radicals and antioxidants. A personal view. Nutr. Rev., 52, 253265.

Hayek, T.; Fuhrman, B.; Vaya, J.; Rosenblat, M.; Belinky, A.P.; Coleman, R.; Elis, A., Aviram, M. (1997). Reduced progression of atherosclerosis in apolipoprotein 6albumin E- deficient mice following consumption of red wine, or its polyphenols quercetin, or catechin is associated with reduced susceptibility of LDL to oxidation and to aggregation. Arterioscler. Thromb. Vasc. Biol., 17, 2744- 2752.

Heinecke, J.W.; Suits, A.G.; Aviram, M. Chait a. (1991). Phagocytosis of lipase- aggregated low density lipoprotein promotes macrophage foam cell formation sequential morphological and biochemical events. Arterioscler. Thromb. 11, 1643- 1651.

Hertong, M.G.; Krombout, D.; Aravains, C. (1995). Flavonoid intake and long time risk of coronary heart disease and cancer in the seven countries study. Arch. Intren. Med. 155, 381-386.

Kim, J. K.; Kim, Y. g.; MinNa, K.; Surh, Y.J.; Kim, T.Y. (2007). [6]- Gingerol prevents UVB- induced ROS production and Cox- 2 expression in vitro and in vivo. Free radical Res., 41(5), 603- 614.

Lam, R.Y. Y.; Woo, A.Y.H.; Leung, P.S.; Cheng, C.H.K. (2007). Antioxidant action of phenolic compounds found in dietary plants on low- density lipoprotein and erythrocytes in vitro. J. Am. Coll. Nutr., Vol. 26(3), 233-242.

Langer, E.; Greifenberg, S.; Gruenwald, J.(1998). Ginger history and use. Adv Ther., 15, 2544 (Review).

Lippoushi, K.; Azuma, K.; Hidekazu, H.; Horie, H.; Higashio, H. (2003). Gingerol inhibits nitric oxide synthesis in activated J774.1 mouse macrophages and prevents peroxynitrate- induced oxidation and nitration reactions. Life Sciences, 73(26), 3427- 3437.

Lishen, C.H.; Jonghong, K.; Kim, S. (2005). Comparitive effects of ginger roots (Zingiber officinale Rosc.) in the reduction of inflammatory mediators in normal and osteoarthrotic sow chondrocytes. J. Med. Food, 8(2), 149- 153.

Masuda, Y.; Kikuzaki, H.; Hisamoto, M.; Nakatani, N. (2004). Antioxidant properties of gingerol related compounds from ginger. Biofactors, 21(1-4), 293- 296.

Murota, K.; Hotta, A.; Ido, H.; Kawai, Y.; MOON, J.H.; Sekido, K.; Hayashi, H.; Inakuma, T.; Terao, J. (2007). Antioxidant after onion consumption in humans. J. Med. Invest., 54(3-4), 370- 374.

Ness, G.C.; Zhao, Z.; Lopez, D. (1996). inhibitor of cholesterol biosynthesis increase hepatic low density lipoprotein receptor protein degradation, Arch. Biochem. Biophys., 325, 242- 248.

O'Brien, B.C.; Reister, R. (1979). Comparative effects of purified and human- type diets on cholesterol metabolism in the rat, J. Nutr., 109, 98- 104.

Ozaki, Y.; Kawahara, N.; Harada, M. (1991). Anti- inflammatory effect of Zingiber cassumunar Roxb. And its active principles. Chem. Pharm. Bull., 39, 2353- 2356. 
Patterson, F.P.; Bartels, D.M.; Hug, G.L.; Freitas, J.P.; Maziere, J.C.; Santus, R.; Morliere, P. (2007). Albumin- bound quercetin repairs vitamin $\mathrm{E}$ oxidized by apolipoprotein radicals in native HDL3 and LDL. Biochemistry, 46(49), 1430514315.

Potts, J.T.; Bringhurst, F.R.; Gradella, T.; Nussbaum, S.R.; Segre, G.V.; Kronenberg, H.M. (1995). "Parathyroid Hormone: Physiology, Chemistry, Biosynthesis, Secretion, Metabolism and Mode of Action". In : Endocrinology. 3rd edn. Vol. 2 L J DeGroot. edn. Philadelphia. W B. Saunders. pp. 920-966.

Shanmugasundaram, K.R.; Ramanujam, S.; Shanmugasundaram, E.R. (1994). Amrita Bindu- a salt- spice- herba health food supplement for the prevention of nitrosamine induced depletion of antioxidants. J. Ethnopharmacol., 42(2), 83- 93.

Sharma, L.; Gusian, D.; Dixit, V.P. (1996). Hypolipidemic and antiatherosclerotic effects of Zingiber officinale in cholesterol fed rabbits, Phyto. Res., 10, 517- 518.

Shen, C. L.; Hong, K.J.; Kim, S.W. (2003). Effect of ginger (Zingiber officinale Rosc.) on decreasing the production of inflammatory mediators in sow osteoarthrotic cartilage explants. J. Med Food, 6(4), 323- 328.

Steel, R. G.; Torrie, J.H. (1980). "Principles and Procedures of Statistics". 2nd edn. New York, Mc Graw- Hill Book Co. Inc., pp: 78- 127.

Suits, A. G.; Chait, A.; Aviram, M.; Heinecke, J.W. (1989). Phagocytosis of aggregated lipoprotein by receptor- dependent foam formation. Proc. Natl. Acad. Sci. 86, 2713- 2717.

Tyler, V. E. (1993). "In the Honest Herbal: A sensible Guide the use of Herbs and Related Compounds", Pharmaceutical Products Press, Binghamton, New York, pp. 209210.

VanAcker, S.A.B.E.; Vander berg, D.J.; Tromp, M.N.J.L.; Griffioen, D.H.; VanBennekom, W. P.; Vander Visgh, W.J.F.; Bast, A. (1996). Structural aspectsof antioxidant activity of flavonoids. Free Radic. Biol. Med., 20, 331-342.

Vanuffelen, B.E.; Vanderzec, J.; Dekoster, B.M. (1998). Biochem. J. 330, 719. Cited by AlZamely et al., (2001).

Wagner, H. (1986). "In Plants Flavonoids in Biology and Medicine, Biochem. Pharmacol. and Structure- Activity Relationships", Alan R. Liss, Inc., New York, pp. 545558.

White, B. (2007). Ginger: an overview, Am. Fam. Physician, 75(11), 1691- 1698.

Wohaieb, S. A.; Tohala, S.H.; Al-Dewachi, O.S. (1994). effect of vitamin $\mathrm{E}$ on $\mathrm{H}_{2} \mathrm{O}_{2}$ induced oxidation stress in rabbits. Iraqi J. Vet. Sci., 7, 81- 84.

Yamaguchi, M.; Hamamoto, R.; Uchiyama, S.; Ishiyama, K. (2007). Effects of flavonoids on calcium content in femoral tissue culture and parathypoid hormone stimulated osteoclastogenesis in bone marrow culture in vitro. Mol. Cell. Biochem., 303(12), 83- 88. 